\title{
Hard Core Europe? Possible Scenarios for the \\ Prospect of Differentiated Integration?
}

\author{
Georgiana CICEO
}

\begin{abstract}
The discussion on differentiated/flexible integration is far from novel. Ever since the first enlargement back in the 1970s a consistent literature started to develop in reaction to the increasing heterogeneity of the political, economic, social preferences and capabilities of the Member States. Differentiated integration received increased consideration in the 1990s against the background of the forthcoming eastward enlargement. Back then, differentiated integration was designed as a possible solution for the loss of homogeneity occurred because of enlargement. Closer to our days, the differentiated integration has made a powerful comeback. The crisis has laid bare the flaws in the design of Economic and Monetary Union. As part of the solutions put forward, an even clearer distinction between euro and non-euro Member States came to dominate the discussions. However, the challenges posed by it are still to be explored especially in view of the ongoing discussion on the reform of the European Union. Proposals for a profound restructuring of the architecture of the EU's economic governance have intensified beginning with 2012 The present article analyses the challenges posed by differentiated integration to the countries remaining at the periphery of the core and to investigate whether they do not threaten to raise new frontiers.
\end{abstract}

Keywords: differentiated integration, EU reform, frontiers

The differentiated course of integration is considered suitable solution for easing the tension between the opposing demands for further deepening of integration and those for enlarging the EU membership. As such, it can be regarded as an useful tool for addressing the ever-growing heterogeneity of the Union: it offers convenient ways out for overcoming not only the discrepancies existing among the individual Member States in terms of economic power, their potential to pursue the deepening of integration or capacity of expanding it into new policy areas, but also their attitude towards the ultimate goals of the entire process of European. Although a commonly acknowledged definition of differentiated integration did not emerged yet, there is considerable overlapping among those put forward so far. For instance, Alex Warleigh considers that differentiated or flexible integration refers to 'the ability of Member States to choose not to participate in particular policies no matter how they are made'. ${ }^{1}$ As a result, it is 'all about allowing the creation of inequalities'. ${ }^{2}$ For Clara Brandi and Michael Wohlgemuth, differentiated

1 Alex Warleigh, Flexible integration. Which Model for the European Union?, New York: Sheffield Academic Press, 2002, p. 4.

2 Alex Warleigh, „Towards Network Democracy? The Potential of Flexible Integration”, in European Integration in the Twenty-First Century: Unity in Diversity?, eds. Mary Farrell, Stefano Fella and Michael Newman, London: Sage, 2002, p. 110. 
integration is a 'general term' employed for explaining 'the possibility of Member States to have different rights and obligations with respect to certain common policy areas'. ${ }^{3}$ It refers to the possibility of having temporary or permanently 'different levels of integration within the EU'. ${ }^{4}$ As far as Dirk Leuffen, Berthold Rittberger, Frank Schimmelfennig are concerned, they define the European 'system of differentiated integration' proceeding from the assumption that the EU refers not to "many Europes" "with task-specific jurisdictions each having their own organization', but to 'one Europe with an organizational and Member State core but with a level of centralization and territorial extension that vary by function'. It is an option that 'allows individual countries to remain at the status quo while others move ahead'. ${ }^{6}$

The discussion on differentiated/flexible integration is far from novel. Various modes of flexible integration have gained over the time considerable prominence in the political debate. Ever since the first enlargement back in the 1970s a consistent literature started to develop in reaction to the increasing heterogeneity of the political, economic, social preferences and capabilities of the Member States. Discussions on differentiated integration received increased consideration in the 1990s against the background of the forthcoming eastward enlargement. Back then, differentiated integration was designed as a possible solution for the loss of homogeneity occurred because of enlargement. Closer to our days, differentiated integration has made a powerful comeback. The crisis has laid bare the flaws in the design of Economic and Monetary Union. As part of the solutions put forward, an even clearer distinction between euro and non-euro Member States came to dominate the discussions.

Ever since its inception, the process of European integration determined the creation of a more or less visible network across the Member States. ${ }^{7}$ One of the major principles enshrined in the Treaty of Rome was that of equal rights and obligations for all member states. A vast 'body of common rights and obligations

3 Clara Brandi and Michael Wohlgemuth, Strategies of Flexible Integration and Enlargement of the European Union. A Club-theoretical and Constitutional Economics Perspective, Freiburg Discussion papers on Constitutional Economics (2006), p. 2, http://www.econstor. eu/handle/10419/4367 (accessed February 21, 2013).

4 Ibidem.

5 Dirk Leuffen, Berthold Rittberger and Frank Schimmelfennig, Differentiated Integration. Explaining Variation in the European Union, Basingstoke: Palgrave Macmillan, 2012, p. 10.

6 Frank Schimmelfennig, Dirk Leuffen, Berthold Rittberger, Ever looser union? Towards a theory of differentiated integration in the EU, EUSA Conference 2011, Boston, p. 12, http:// www.euce.org/eusa/2011/papers/9g_schimmelfennig.pdf (accessed February 21, 2013).

7 Cristina-Maria Dogoț, "How Permeable or Impermeable Could Be the Borders? Introduction", Eurolimes no. 13: Permeability and Impermeability of Socio-Economic Frontiers within the European Union, ed. Violaine Delteil, Cristina-Maria Dogoț, Kozma Gabor and Jarosław Kundera, Oradea: Oradea University Press, 2012, pp. 5-8. 
which bind all the Member States together within the European Union'8 known as the acquis communautaire has been developed over the years. Nevertheless, in parallel another set of rules that concerns only a limited number of Member States has also paved its way and has come to raise vital questions about the nature and direction of the process of European integration. If thus far it was supposed that the differentiation is having just a temporary character, it becomes gradually more obvious that we are heading towards a situation where it contributes to the creation of permanent different standings inside the very same European family. Furthermore, differentiated integration additionally burdens the democratic credibility of European integration ${ }^{9}$ and generates fears of future inner borders inside the EU, 'separating people despite the fact that they are not physical'. ${ }^{10}$

Various modes of flexible integration have gained over time considerable prominence in the political debate. Alexander Stubb divided the existing political conceptions of differentiated integration into three principal categories/models: $1 . /$ multi-speed, 2./ variable geometry and 3./ à la carte, by using three variables time, space and matter. ${ }^{11}$ Although each of the proposed models conveys a series of often subtle distinctions and implies different strategies for action, all stem from a similar diagnosis of the EU's malady: namely, that of seeking to apply excessively strict common goals and disciplines to countries, which in fact are strikingly diverse. Despite the fact that a certain number of variants of the above-mentioned models emerged in the mean time ${ }^{12}$, for the purpose of this discussion we will preserve Stubb's categorization.

The multi-speed model, the oldest among the three, whose origins stretch as far back as the beginning of the 1970s when the first enlargement round of the EC took place and consequently a debate on the need of solving the problem of growing heterogeneity of the EC started, proceeds from the assumption that while all the Member States want to reach the same integration goal, they do not have equal abilities and hence they reach this goal at different speeds. Some countries that are capable and willing to take a step forward in the integration reach the identified goal rather quickly whereas the other countries join

8 ***, "Community acquis", http://europa.eu/legislation_summaries/glossary/community_ acquis_en.htm (accessed February 21, 2013).

9 Alex Warleigh, Democracy in the European Union: Theory, Practice and Reform, London: Sage, 2003, pp. 72-74.

10 Ioan Horga, Mircea Brie, "Europe between Exclusive Borders and Inclusive Frontiers", Studia Universitatis Babeş-Bolyai Studia Europaea, nr. 1, vol. LV (2010), p. 83.

11 Alexander C.-G. Stubb, "A categorization of differentiated integration", Journal of Common Market Studies, no. 2, vol. 34 (1996), pp. 283-295.

12 See for instance Warleigh, Democracy in the European Union, pp. 70-71. 
in later according to their capabilities and political will. ${ }^{13}$ From this perspective, the principal variable is time as differentiation in the level of integration of respective Member States is considered just an exceptional, temporary solution, not a permanent. The model revolves around a core - an 'avant-garde"14 or 'enhanced cooperation' or 'consolidated cooperation' group, consisting of those states which are willing and capable to integrate in a wider range of policies. For the sake of effective reaching of integration goals, they oblige themselves to a long-term sharing of common strategic and tactical interests. Different politicians envisaged different designs for this core, the most prominent remaining those put forward by Wolfgang Schäuble and Karl Lamers in $1994^{15}$ and Joshka Fischer in $2000^{16}$ as possible solutions for dealing with the accession of Central and Eastern European Countries to the European Union. The former shaped the center in the form of a 'hard-core' consisting of an elite club of Member States (France, Germany, Belgium, the Netherlands and Luxembourg), created with the aim of preventing the other, which are currently either unable or for some reasons hesitating, from hindering their determination to move ahead the process of integration. The other states could follow suit, but their admission in the inner circle remained dependent upon their capacity to assume the necessary obligations. The proposal generated immediately after its publication a wave of criticism equally from the supposed ins and outs. While the smaller countries inside the 'hard-core' felt themselves uneasy because of the Franco-German domination, those remaining outside regarded the proposal as too exclusivist because they feared that they might be treated as second-class members. The core in the vision of Joshka Fischer would resemble a 'centre of gravity' made of 'those states that want to cooperate more closely than others, as is already the case with the Economic and Monetary Union and with Schengen'. This group of states 'would conclude a new European framework treaty, the nucleus of a constitution of the Federation', on the basis of which 'the Federation would develop its own institutions, establish a government that within the EU should speak with one voice on behalf of the members of the group on as many issues as possible'. The 'center of gravity' would have to be the avant-garde, the driving force for the completion of political integration, and it should from the start comprise all the elements of

13 Stubb, p. 285.

14 Jacques Delors, An „Avant-garde” driving the European unification process forward. Speech at International Bertelsmann Forum „Europe without borders“, Berlin, January 19-20, 2001, http://www.eng.notre-europe.eu/ (accessed February 15, 2013).

15 Wolfgang Schäuble, Karl Lamers, Überlegungen zur europäischen Politik. Position Paper of the CDU/CSU-Bundestagsfraktion, September 1, 1994, http:/www.cducsu.de/upload/ schaeublelamers94.pdf (accessed February 21, 2013).

16 Joshka Fischer, From Confederacy to Federation: Thoughts on the Finality of the European Integration, Berlin: Humboldt University, May 12, 2000. http://germanhistorydocs.ghi-dc. org (accessed February 15, 2013). 
the future federation' ${ }^{17}$ Neither this model did manage to break out without a good deal of criticism. However, it is necessary to be mentioned that around the center there is also a periphery which includes the countries that are either unable to achieve the level of integration of the core states (the laggards) or unwilling to do so (the opt-outs).

The model of variable geometry is based on the premise that the differences among the Member States could hamper EU's ability to achieve the necessary coherence. According to the definition of the European Commission, the term is 'used to describe the idea of a method of differentiated integration which acknowledges that there are irreconcilable differences within the integration structure and therefore allows for a permanent separation between a group of Member States and a number of less developed integration units'. ${ }^{18}$ This means that, on the one hand, there are Member States, which are not capable of reaching a particular level of integration. On the other hand, there are Member States for whom some policy areas are so sensitive in term of national interest that they are not willing to agree with expanding of integration into these policy areas. In a similar manner with the multi-speed model, the present one also takes into consideration the reality of a core and of a periphery, but in contrast with its challenger admits that there are differences with regard to the integration goals of individual Member States and the policy areas that they are ready to open for integration (not only with regard to their speeds of integration). Therefore, the model of variable geometry is considered as a compromise between the supranational and intergovernmental approach to the integration. It is often associated with the model of 'concentric circles' advanced in 1994 by the at that moment French Prime Minister, Edouard Balladur. In an interview for the French daily paper Le Figaro on August 30 of that year, he stated that Europe should consist of three concentric circles. ${ }^{19}$ The inner circle should comprise the Member States closely integrated in economic and monetary sphere as well as in the defense matters (EU core); a system of states based on existing Treaties (all the EU Member States) constitute another circle; and the third outer circle comprise other states of Europe that have established contractual relationship with the EU. A variant of the model concentric cir-

17 Fischer, pp. 9-10.

18 ***, "Variable geometry", http://europa.eu/legislation_summaries/glossary/variable_ geometry_europe_en.htm (accessed February 21, 2013).

19 The first to coin the term 'concentric circles' was Christopher Tugendhat, former British Commissioner and Vice-President of the European Commission, who, in a lecture delivered in 1984, considered this conception as a moderate version of variable geometry. See Christopher Tugendhat, Europe - What Matters Now, The Swinton Lecture, Cambridge, July 14, 1984, http://aei.pitt.edu/12017/1/12017.pdf (accessed February 21, 2013). Further, the idea was taken up by Jacques Delors and promoted in reaction to the events of 19891991. See Helen Wallace and William Wallace, Flying together in a larger and more diverse European Union, The Hague: The Scientific Council for Government policy, 1995, p. 62. 
cles would be the one of 'polycentric circles' that goes very much in the direction of a Europe à la carte.

The least orthodox of the three models of differentiated integration is the $a$ la carte one, designed for the first time by Ralf Dahrendorf in $1979^{20}$ in response to the stagnation that gripped integration throughout the 1970s. Based on the principles of intergovernmentalism, the model, as the metaphor of the menu of a restaurant from where it derives its name might suggest, considers that the Member States should be given the possibility of choosing from a variety of policy areas the ones in which they wish to participate (the matter of integration) by preserving a minimum of common goals ${ }^{21}$ - 'that is common policies where there are common interests without any constraint on those who cannot, at a given point of time, join them' ${ }^{22}$ After being opposed to any form of differentiated integration for the most part of the 1980s out of conviction that by preserving uniformity it could determine the speed of the entire integration process and would prevent it to 'spillover' into sensitive policy areas, UK shifted towards an à la carte model against the background of the negotiations on the Maastricht Treaty, not because it had completely abandoned its fears of losing influence if flexibility was to be considered a principle of EU governance, but because it wanted to counter the German concept of 'hard core' and the French one of 'concentric circles'. ${ }^{23}$ In 1994, in a speech at the Leiden University, the then Prime Minister John Major, while recoiling from the idea of a Europe with a core and a periphery 'in which some would be more equal than others', stated his view according to which 'no Member State should lay claim to a privileged status on the basis of its participation' in some of the common policies or areas of close co-operation. ${ }^{24}$ On the contrary, only 'flexible arrangements allow countries freedom and choice on how they decide to participate in the pursuit of our shared aims'. ${ }^{25}$

The first treaty departure from the imperative of uniformity was made in the context of the Treaty of Maastricht in order to allow for the implementation of far reaching policies such as the monetary union. It was only with the Treaty of

20 Ralf Dahrendorf, A Third Europe? Third Jean Monnet Lecture, Florence: European University Institute, November 26, 1979, http://aei.pitt.edu/11346/2/11346.pdf (accessed February 21, 2013).

21 Under the minimum of common goals, an institutionalized economic cooperation (e.g. the common market) is mostly understood.

22 Dahrendorf, pp. 20-21.

23 Warleigh, Flexible integration, p. 15.

24 John Major, Speech at the William and Mary Lecture, Leiden University, September 7, 1994, http://www.johnmajor.co.uk/page1124.html (accessed February 21, 2013).

25 Ibidem. 
Amsterdam that flexibility was introduced as a principle of governance in the EU. The Treaty of Nice brought with it further clarifications with regard to the implementation of this principle. With the Treaty of Lisbon, a number of new avenues for advancing with the differentiated integration have been opened. At first, came the Charter of Fundamental Rights included in the Treaty, but not fully applicable to countries like Poland or UK. Then, gradually a number of other pieces of legislation came to supplement the already well-established enhanced cooperation in terms of foreign and security policy and justice and home affairs. For instance, only fourteen Member States adopted a Regulation on the right of international couples to choose which law to apply to their divorce at the moment of their marriage, thus preventing costly litigations, both economically and emotionally in $2010 .{ }^{26}$ In response to the fact that the existing legislation on a 'European patent' developed within the framework of the European Patent Office, was nothing more than the sum of the individual countries' patents, in 2012 a Regulation on a unitary patent ${ }^{27}$ was adopted after difficult negotiations by all EU Member States but Spain and Italy who opposed the document for linguistic reasons. ${ }^{28}$ Closer to our days, we have a highly divisive European Commission proposal for a tax on financial transactions that gathers the support of only 11 EU Member States and tends to become a test of 'how far groups of countries are willing to plough ahead on economic legislation and leave others behind'. ${ }^{29}$ The proposed document does not enjoy even the support of all the euro zone countries despite the fact that taxation is so closely linked to member states' economies and could have an impact on non-participating countries.

Nevertheless, Economic and Monetary Union and the Schengen Agreement preserve a definite ascendancy over the various experiments in differentiated integration carried out so far. A comparative analysis about the impact of flexibility on 15 case studies from five policy areas undertaken by Alkuin Kölliker managed to highlight in an authoritative way the progressive advance of differentiated

26 European Commission, Lithuania is the 15th EU Member State to sign up to enhanced cooperation rules to help international couples, Press Release, November 20, 2012, http:// europa.eu/rapid/press-release_IP-12-1231_en.htm (accessed February 21, 2013).

27 European Parliament and the Council of the European Union, Regulation No 1257/2012 implementing enhanced cooperation in the area of the creation of unitary patent protection, December 17, 2012, http://eur-lex.europa.eu/LexUriServ/LexUriServ.do?uri=OJ:L:2012:36 1:0001:0008:EN:PDF (accessed February 21, 2013).

28 Carlo Maria Cantore, "We're one, but we're not the same: Enhanced Cooperation and the tension between unity and asymmetry in the EU", Perspectives on Federalism, Issue 3, Vol. 3 (2011): E - 13.

29 Ian Wishart, "The divisive tax", European Voice, February 21, 2013, http://www. europeanvoice.com/article/imported/the-divisive-tax/76473.aspx (accessed February 21, 2013). The 11 countries are: Austria, Belgium, Estonia, France, Germany, Greece, Italy, Portugal, Slovakia, Slovenia, Spain. 
integration from the mid-1980s to the end of the 1990s. ${ }^{30}$ Moving the discussion forward to the present day, it turns out that the experience acquired up to now in differentiated integration indicates a certain preference for the multi-speed model, while there are still no notable examples for the use of the variable geometry model. In the practice of the European Union, it is also possible to find some examples converging towards the à la carte model or at least borrowing some of its features. Primarily it is the option of the so-called 'opt-out', or if you like, the option of negotiating an exemption from some policy provisions or even from the whole policies. According to Alex Warleigh ${ }^{31}$, one can sense a certain preference for the multi-speed model when it comes to policies with a predominant Community method of policy making because of the significant powers of the Commission and European Parliament, who tend to protect both small states and 'the general European interest' by preventing the emergence of a 'hard core'. At the other end of the spectrum there are the transgovernmental policies in the classification of Helen Wallace ${ }^{32}$ in which case the preferences have a tendency towards the à la carte model as usually clusters of member states agree to cooperate on various policy issues.

Apart from the legal provisions that open the possibility for differentiated cooperation in common foreign and security policy and justice and home affairs, there are a number of other possibilities for advancing in this direction. Firstly, we have the option of starting the integration outside the existing treaty framework and bringing it inside at a later point as it was the case with the Schengen Agreement. Secondly, it is possible to make use of the provisions of the Art. 114(4) Treaty on the Functioning of the European Union (TFEU), according to which 'if,[...], a Member State deems it necessary' can 'maintain national provisions on grounds of major needs referred to in Article $36^{33}$, or relating to the protection of the environment or the working environment'. Finally yet importantly, differentiated integration can proceed based on those provisions referring to enhanced cooperation. Art. 20(1) of the Treaty on the European Union (TEU) states that 'Member States which wish to establish enhanced cooperation between themselves within the framework of the Union's non-exclusive competences may make use of its institutions and exercise those competences by applying the relevant provisions of the Treaties'.

30 Alkuin Kölliker, Flexibility and European Unification: The Logic of Differentiated Integration, New York: Rowman and Littlefield, 2006.

31 Warleigh, Flexible integration, p. 12.

32 Helen Wallace, "An Institutional Anatomy and Five Policy Modes", Policy-Making in the European Union, eds. Helen Wallace, Mark A. Pollack and Alasdair Young, 6-th ed., Oxford: Oxford University Press, 2010, pp. 100-102.

33 Public morality, public policy or public security; the protection of health and life of humans, animals or plants; the protection of national treasures possessing artistic, historic or archaeological value; or the protection of industrial and commercial property. 
Over the years, differentiated integration came to be seen as a 'way to find compromise and avoid log jam' 34 and a useful 'tool for the management of diversity' ${ }^{35}$ Despite the fact that according to Art. 20(1) TEU '[e]nhanced cooperation shall aim to further the objectives of the Union, protect its interests and reinforce its integration process' and that '[s] uch cooperation shall be open at any time to all Member States', differentiated integration cannot be regarded as a panacea for the problem of boosting the completion of the European construction. As a principle of EU governance, differentiated integration or flexibility remains divisive. Its proponents have to 'assuage the concerns of many actors at both EU and national levels and show that it can deepen (or at least not impede) integration' ${ }^{36}$

Differentiated integration generates anxiety as it opens a line of fracture with a long-established EU principle, namely, that of solidarity, which was part and parcel of the European project ever since its launch. It was generally considered that, if people are 'to give their full support to and participate fully in European integration', greater emphasis must be placed on 'their common cultural values and roots as a key element of their identity and their membership of a society' founded among other essential principles on solidarity. ${ }^{37}$ European solidarity can be read in many keys, but the most relevant for the present discussion is the one of constructing a lasting cross-national sense of unity. In this respect, the common policies, which lie at the heart of the European policy-making, are bound to 'give substance to the solidarity' that binds Member States' economies and currencies ${ }^{38}$. Now, restoring the credibility and integrity of the economic and monetary union has brought in sight the perspective of building up four unions- a banking union for the recovery of the financial stability, a fiscal union for achieving the goal of fiscal stability and for facing public finance challenges, an economic union to support growth, and a political union for redressing the long established problem of the democratic legitimacy. Out of the four proposed unions, the project of building a banking union is by far the most advanced. However, each of the four unions and the banking union in particular raise concerns that the line, which has

34 Alexander C.-G. Stubb, "The 1996 Intergovernmental Conference and the management of flexible integration", Journal of European Public Policy, no. 1, vol. 4 (1997), p. 47.

35 Warleigh, Democracy in the EU, p. 68.

36 Ibidem, p. 69.

37 European Parliament and the Council of the European Union, Decision No 1855/2006/EC establishing the Culture Programme (2007 to 2013), December 12, 2006, http://eur-lex. europa.eu/LexUriServ/LexUriServ.do?uri=OJ:L:2006:372:0001:0011:EN:PDF (accessed February 21, 2013).

38 Leo Tindemans, Report on the European Union, Bulletin of the European Communities Supplement 1/1976, http://aei.pitt.edu/942/1/political_tindemans_report.pdf (accessed February 21, 2013). 
been drawn since 2002 between the euro and non-euro area Member States, would lose its provisional character (as with the exception of the three opt-outs - United Kingdom, Denmark and Sweden, the other countries had an obligation to enter the euro area $)^{39}$ and become more entrenched and have implications with regard to the voting power and the influence of non-euro countries.

That is why in his speech on the State of the Union in 2012, the president of the European Commission felt himself compelled to emphasize that 'in Europe, we need no more walls dividing us!' ${ }^{40}$ While insisting on the necessity of completing the economic and monetary union, which is essential to be supplemented by a genuine banking union and a fiscal union, the Commission President stressed that they would have to be properly equipped with institutional and political mechanisms. The inevitable reform of the treaty framework that can start after the 2014 European elections will have to provide the solutions for building a 'federation of states' in which ' $[\mathrm{n}] \mathrm{o}$ one will be forced to come along. And no one will be forced to stay out. The speed will not be dictated by the slowest or the most reluctant' ${ }^{41}$ Although the assurances are that 'there is only one European Union. One Commission. One European Parliament' ${ }^{\text {'2 }}$, the fact that according to Art. 20(1) TEU '[a]11 members of the Council may participate in its deliberations, but only members of the Council representing the Member States participating in enhanced cooperation shall take part in the vote' is generating the discomfort of those who will not participate in the decision making.

For instance, in a country like the United Kingdom whose government decided not to participate in the banking union, the House of Lords issued in conclusion of a long series of debates on the future of economic and monetary integration a report that states that ' $[\mathrm{w}] \mathrm{e}$ are deeply concerned that closer integration of an inner core of Member States could threaten the integrity of the single market' ${ }^{43}$ As it is evident that the euro area would remain one of its key trading partners, the members of the UK Parliament could not afford to remain complacent with the current events and ignore the many legal and political intricacies of the project. The fear is that a certain 'degree of marginalization will be inevitable as the euro area (and possibly other Member States) take steps towards deeper integration' ${ }^{44}$ This feel-

39 Jacques Bourrinet, "L'évolution de la zone euro au travers de la plasticité de ses frontières", Eurolimes no. 8: Europe and its Economic Frontiers, ed. Luminița Şoproni, Angelo Santagostino and Ernő Molnar, Oradea: Oradea University Press, 2009, pp. 10-14.

40 José Manuel Durão Barroso, State of the Union 2012, Address to the Plenary session of the European Parliament, Strasbourg, September 12, 2012, http://europa.eu/rapid/press-release SPEECH-12-596_en.htm (accessed February 21, 2013).

41 Ibidem.

42 Ibidem.

43 House of Lords, European Union Committee, European Banking Union: Key issues and challenges, 7thReport of Session 2012-13, December 12,2012, http://www.publications. parliament.uk/pa/ld201213/ldselect/ldeucom/88/88.pdf (accessed February 21, 2013), p. 42. 44 Ibidem, p. 41. 
ing might be reinforced by the prospect that "euro area countries and other participating Member States will converge towards common positions in a number of areas. This may place an EU-27 single market under severe strain, in particular if a majority of non-euro Member States chooses to participate in banking union'. ${ }^{45}$ The House of Lords Report cautions that the banking union proposals hide the risk of losing the cohesion of the European structure as this is now redesigned in the form of a construction with a variable geometry.

Especially the idea of creating a new institutional setup for the governance of the economic and monetary union meets with restraint within certain corners of the EU polity. Martin Schultz, the President of the European Parliament, was insisting that 'there is no need whatsoever to create new, parallel Unions and new, parallel institutions'. In the context of euro zone governance as well, 'the integrity of the Community institutions must be safeguarded'. When it comes to reforms, these will have to enable 'the 25 Member States which are keen to take part in all EU policies to do just that' ${ }^{46}$ His views are reinforced by the Thyssen Report, which considers it necessary 'to place the governance of the EMU within the institutional framework of the Union' and 'to proceed swiftly by maximizing the possibilities given by the existing Treaties and their elements of flexibility'. ${ }^{47}$

In the hitherto discussions on the creation of the banking union the concerns of the non-euro area countries have been largely assuaged. The proposed documents on the creation of the Single Supervisory Mechanism (SSM) and on the modifications to the functioning of the European Banking Authority contain important safeguards for the non-euro Member States. Accordingly, although the Treaty of Lisbon places the highest decision making authority in the European Central Bank (ECB) with the Governing Council in which the non-euro Member States have no vote, in the SSM, the decisions will be drafted by a Supervisory Board in which each participating state has one vote acting by simple majority ${ }^{48}$ and enter into force if the Governing Council of the ECB does not object them in a period of 10

45 Ibidem, p. 42.

46 Martin Schulz, Speech to the European Council, October 18, 2012, http://www. socialistsanddemocrats.eu/gpes/media3/documents/4057_EN_schulz_council_en_121018. pdf (accessed February 15, 2013).

47 Marianne Thyssen, Report with recommendations to the Commission on the report of the Presidents of the European Council, the European Commission, the European Central Bank and the Eurogroup "Towards a genuine Economic and Monetary Union", A7-0339/2012, October 24, 2012, http://www.europarl.europa.eu/sides/getDoc.do?pubRef=-//EP// NONSGML+REPORT+A7-2012-0339+0+DOC+PDF+V0//EN\&language $=\mathrm{EN} \quad$ (accessed February 15, 2013), p. 18.

48 Council of the European Union, Proposal for a Council regulation conferring specific tasks on the ECB concerning policies relating to the prudential supervision of credit institutions, 17812/12, December 14, 2012, http://register.consilium.europa.eu/pdf/en/12/st17/st17812. en12.pdf (accessed February 15, 2013), Art. 19 (2ab). 
days. When a non-euro Member State objects an observation of the Governing Council to a draft proposal of the Supervisory Board, the Governing Council will, according to the current proposal, have to give an opinion on the reasoned disagreement expressed by the Member State and, stating its reasons to do so, confirm or withdraw its objection. ${ }^{49}$ The relations of the non-euro Member States with the proposed mechanism, as opt-ins with no voice in the Governing Council of the $\mathrm{ECB}$, are further detailed in many other articles of the future Regulation, which leads to the conclusion that even though the Treaty provides a 'relatively narrow basis for the involvement of the non-euro countries', yet it 'provides strong safeguards to protect' their interests..$^{50}$

In the mean time, with regard to the next steps in the direction of the overall reform of the EU treaty framework, the opinions of the European leaders are split between the Angela Merkel's perceived need for greater 'Europeanization of national powers', David Cameron's aspiration towards denationalization of European powers, and François Hollande's vision of a stronger political union. ${ }^{51}$ Angela Merkel proceeds from the imperative of renewing the foundations of economic and monetary union. In order to dissipate the fears of those concerned of the prospect of a possible 'division between an EU of the 17 and of the 27, soon to be 28 ' she stresses that the renewed economic and monetary union is 'no closed club of euro countries' and 'does not lead to a two-speed Europe but, rather, creates a double-strength European Union'. However, she considers that there is necessary to decide 'whether only parliamentarians from the euro countries should be allowed to vote on such matters', but 'without establishing an additional parliamentary institution'. ${ }^{52}$ David Cameron, while mulling over the alternatives available for shaping the future of Europe, has come to the conclusion that any discussion will need to have as starting point the observation that 'we are a family of democratic nations, all members of one European Union, whose essential foundation is the single market rather than the single currency'. He agrees that at some stage in the next few years 'some big institutional changes' will become a must for 'the long term future of the Euro'. Yet, these will have to work fairly for those inside and outside the euro zone as it is 'a vital interest for us to protect the integrity and fairness of the single market for all its members'. The structure to be created will need to 'accommodate the diversity of its members' and to enable Europe 'to act with

49 Ibidem, Art. 6 (6ab).

50 Zsolt Darvas and Guntram B. Wolff, Should non-euro area countries join the SSM?, http:// www.eu-oplysningen.dk/upload/application/pdf/175b0f18/dkparlpaperformatted.pdf (accessed February 15, 2013).

51 ***, „Charlemagne: Europe à l'Hollandaise. François Hollande's flawed vision for Europe”, The Economist, (February 9-15, 2013), p. 27.

52 Angela Merkel, Speech by Federal Chancellor Angela Merkel in the European Parliament, Brussels, November 07, 2012, http://www.bundesregierung.de/Content/EN/ Reden/2012/2012-11-07-merkel-eu.html (accessed February 15, 2013). 
the speed and flexibility of a network, not the cumbersome rigidity of a bloc'.$^{53}$ For François Hollande, Europe 'cannot be limited to a market, a budget, a currency, irrespective of their value', in the very same manner as it cannot be equated with a 'sum of treatises' or a 'compound of rules'. Neither can Europe survive as an 'accumulation of nations in which each of these comes to seek what is useful for itself and only for itself'. His solution lies in a 'differentiated Europe' which by no means is either a 'two speed Europe', because this would swiftly become imbalanced, or an à la carte Europe, because this would mean a divided Europe. With regard to the future institutional setting, the French vision is also relatively blurred. It is ready to accept the euro governance, new financial instruments and under certain conditions a budget for the euro zone, that will need to be connected to the budget of the European Union. ${ }^{54}$

As such, the British vision exposes little overlapping with both the German and in particular the French ones. However, it is obvious that all the three leaders agree that a new blueprint of the institutional framework is necessary and that a Europe with two speeds is not for the time being a convenient solution. 'The euro area is not likely to become a federal state in the traditional sense of the term in the near future' ${ }^{55}$ Moreover, they find common ground with respect to the need for a democratic scrutiny of the institutions and decision-making processes by the European and national parliaments depending on the level of decision. In addition they favor a more efficient use of the mechanisms for enhanced cooperation already existing in the treaties as these perceived as tools for effective policy-making rather than tools for building a 'core Europe'. ${ }^{56}$ The overall decisions taking by now with regard to the banking union with its joint banking supervision and the and enhanced cooperation in fiscal and budgetary policy seem to reinforce this trend and add credibility to the political discourse on future reform irrespective of how elusive this might be right now.

Differentiated integration has been an important element of the political agenda and academic thinking on European integration for a long time. After the collapse

53 David Cameron, EU Speech at Bloomberg, January 23, 2013, www.number10.gov.uk/news/ eu-speech-at-bloomberg/ (accessed February 15, 2013).

54 François Hollande, Intervention devant le Parlement Européen, Strasbourg, February 5, 2013, http://www.relaunchingeurope.eu/sites/default/files/05\%2002\%2013\%20Discours \%20 du $\% 20$ pr\%C3\%A9sident $\% 20$ de $\% 201 \mathrm{a} \% 20 \mathrm{R} \% \mathrm{C} 3 \%$ A9publique $\% 20$ au $\% 20$ Parlement $\% 20$ europ\%C3\%A9en\%20de\%20Strasbourg.pdf (accessed February 15, 2013), p. 5.

55 Francesco Paolo Mongelli, The Mutating Euro Area Crisis. Is The Balance Between "Sceptics" and "Advocates" Shifting?, Occasional Paper 144, February 2013, http://www. ecb.int/pub/pdf/scpops/ecbocp144.pdf (accessed 15 February 2013).

56 Funda Tekin and Wolfgang Wessels, Flexibility within the Lisbon Treaty: Trademark or Empty Promise?, EIPASCOPE, no. 1 (2008), p. 27. 
of the communist regimes in Central and Eastern Europe with the ensuing aspirations of these countries to become members of the European Union, the differentiated integration received increasing consideration, as it was perceived as a useful tool for handling diversity. In response to the forthcoming Eastern enlargement three designs of differentiated integration have come to gain prominence - multispeed, variable geometry and $\grave{a}$ la carte, each with a long established history behind and enjoying the preferences of one of the big Member States - Germany, France and United Kingdom, respectively. In response to the growing pleas for improving flexibility a number of ways were envisaged for allowing a group of countries to develop in a faster way their own process of integration in a determined policy area by leaving others behind. The most powerful of these remains by far that of enhanced cooperation introduced by the Treaty of Amsterdam and improved later by the treaties of Nice and Lisbon. Derogations from EU policies have been granted over time to many EU countries. However, the distinction between euro and noneuro area Member States has risen over the time concerns regarding the future position and voting power of the latter in the future. Against the background of the crisis, a number of overarching reforms have already been put in practice or just planned. While all non-euro area countries agree that the envisaged reforms offer a window of opportunity for consolidating a "genuine political integration", they fear losing their political influence in the reformed European Union and being sidelined at the border of the euro area. The analysis of the current discussion on differentiated integration and the measures already put in practice does not appear to reinforce the apprehension of the non-euro Member States. However, they have to bear in mind the fact that they cannot enjoy the same benefits from the mechanisms set in motion as the euro area countries even if they decide to participate in these.

\section{Bibliography}

Barroso, José Manuel Durão. State of the Union 2012, Address to the Plenary session of the European Parliament, Strasbourg, September 12, 2012. http://europa.eu/rapid/press-release_SPEECH-12-596_en.htm (accessed February 21, 2013).

Bourrinet, Jacques. "L'évolution de la zone euro au travers de la plasticité de ses frontières", Eurolimes no. 8: Europe and its Economic Frontiers, ed. Luminița Şoproni, Angelo Santagostino and Ernő Molnar. Oradea: Oradea University Press, 2009: 9-17.

Brandi, Clara; Wohlgemuth, Michael. Strategies of Flexible Integration and Enlargement of the European Union. A Club-theoretical and Constitutional Economics Perspective. Freiburg Discussion papers on Constitutional Economics, 2006, http://www.econstor.eu/hand1e/10419/4367 (accessed February 21, 2013).

Cameron, David. EU Speech at Bloomberg, January 23, 2013. www.number10.gov.uk/news/ eu-speech-at-bloomberg/ (accessed February 15, 2013).

Cantore, Carlo Maria. "We're one, but we're not the same: Enhanced Cooperation and the tension betweenunity and asymmetry in the EU". Perspectives on Federalism, Issue 3, Vol. 3 (2011): E-1-21. 
Council of the European Union. Proposal for a Council regulation conferring specific tasks on the ECB concerning policies relating to the prudential supervision of credit institutions, 17812/12. December 14, 2012, http://register.consilium.europa.eu/pdf/en/12/st17/st17812. en12.pdf(accessed February 15, 2013).

Dahrendorf, Ralf. A Third Europe? Third Jean Monnet Lecture. Florence: European University Institute, November 26, 1979. http://aei.pitt.edu/11346/2/11346.pdf (accessed February 21, 2013).

Delors, Jacques. An „Avant-garde” driving the European unification process forward. Speech at International Bertelsmann Forum ,Europe without borders“, Berlin, 19 - 20 January 2001. http://www.eng.notre-europe.eu/ (accessed February 21, 2013).

Dogoț, Cristina-Maria".How Permeable or Impermeable Could Be the Borders? Introduction". Eurolimes no. 13: Permeability and Impermeability of Socio-Economic Frontiers within the European Union, ed. Violaine Delteil, Cristina-Maria Dogoț, Kozma Gabor and Jarosław Kundera, 5-8. Oradea: Oradea University Press, 2012.

European Commission. Lithuania is the 15th EU Member State to sign up to enhanced cooperation rules to help international couples, Press Release, 20 November 2012. http://europa.eu/ rapid/press-release_IP-12-1231_en.htm(accessed February 21, 2013).

European Parliament and the Council of the European Union. Regulation No 1257/2012 implementing enhanced cooperation in the area of the creation of unitary patent protection. December 17, 2012. http://eur-lex.europa.eu/LexUriServ/LexUriServ.do?uri=OJ:L:2012:36 1:0001:0008:EN:PDF (accessed February 21, 2013).

European Parliament and the Council of the European Union. Decision No 1855/2006/EC establishing the Culture Programme (2007 to 2013). December 12, 2006. http://eur-lex. europa.eu/LexUriServ/LexUriServ.do?uri=OJ:L:2006:372:0001:0011:EN:PDF (accessed February 21, 2013).

The Federal Trust for Education and Research. Flexible Integration and the European Constitution. European Policy Brief, nr. 12 (2005). http://www.fedtrust.co.uk (accessed February 15, 2013).

Fischer, Joshka. From Confederacy to Federation: Thoughts on the Finality of the European Integration, Berlin: Humboldt University, May 12, 2000. http://germanhistorydocs.ghi-dc. org (accessed February 15, 2013).

Hollande, François. Intervention devant le Parlement Européen, Strasbourg, February 5,2013. http://www.relaunchingeurope.eu/sites/default/files/05\%2002\%2013\%20Discours\%20 du $\% 20 \mathrm{pr} \% \mathrm{C} 3 \%$ A 9 sident $\% 20 \mathrm{de} \% 201 \mathrm{a} \% 20 \mathrm{R} \% \mathrm{C} 3 \%$ A9publique $\% 20 \mathrm{au} \% 20$ Parlement $\% 20$ europ\%C3\%A9en\%20de\%20Strasbourg.pdf (accessed February 15, 2013).

Horga, Ioan; Brie, Mircea. "Europe between Exclusive Borders and Inclusive Frontiers". Studia Universitatis Babeş-Bolyai Studia Europaea, nr. 1, vol. LV (2010): 63-87.

House of Lords, European Union Committee, European Banking Union: Key issues and challenges, 7th Report of Session 2012-13, December 12, 2012, http:/www.publications.parliament.uk/pa/ld201213/ldselect/ldeucom/88/88.pdf (accessed February 21, 2013).

Kölliker, Alkuin. Flexibility and European Unification: The Logic of Differentiated Integration. New York: Rowman and Littlefield, 2006.

Leuffen, Dirk; Rittberger, Berthold; Schimmelfennig, Frank. Differentiated Integration. Explaining Variation in the European Union. Basingstoke: Palgrave Macmillan, 2012.

Major, John. Speech at the William and Mary Lecture, Leiden University, September 7, 1994. http://www.johnmajor.co.uk/page1124.html (accessed February 21, 2013).

Merkel, Angela. Speech by Federal Chancellor Angela Merkel in the European Parliament, Brussels, November 07, 2012. http://www.bundesregierung.de/Content/EN/ Reden/2012/2012-11-07-merkel-eu.html (accessed February 15, 2013). 
Schäuble, Wolfgang, Lamers, Karl. Überlegungen zur europäischen Politik. Position Paper of the CDU/CSU-Bundestagsfraktion, September 1, 1994. http://www.cducsu.de/upload/schaeublelamers94.pdf (accessed February 21, 2013).

Schimmelfennig, Frank; Leuffen, Dirk; Rittberger, Berthold. „Ever looser union? Towards a theory of differentiated integration in the EU'. EUSA Conference 2011, Boston. http://www. euce.org/eusa/2011/papers/9g_schimmelfennig.pdf (accessed February 21, 2013).

Schulz, Martin. Speech to the European Council, October 18, 2012.http://www.socialistsanddemocrats.eu/gpes/media3/documents/4057_EN_schulz_council_en_121018.pdf (accessed February 15, 2013).

Stubb, Alexander C.-G. "A categorization of differentiated integration". Journal of Common Market Studies, no. 2, vol. 34 (1996): 283-295.

Stubb, Alexander C.-G. "The 1996 Intergovernmental Conference and the management of flexible integration". Journal of European Public Policy, vol. 4, no. 1 (1997): 37-55.

Tekin, Funda; Wessels, Wolfgang. Flexibility within the Lisbon Treaty: Trademark or Empty Promise?. EIPASCOPE, no. 1 (2008): 25-31.

Thyssen, Marianne. Report with recommendations to the Commission on the report of the Presidents of the European Council, the European Commission, the European Central Bank and the Eurogroup "Towards a genuine Economic and Monetary Union", A7-0339/2012, October 24, 2012. http://www.europarl.europa.eu/sides/getDoc.do?pubRef=-//EP// $\mathrm{NONSGML}+\mathrm{REPORT}+\mathrm{A} 7-2012-0339+0+\mathrm{DOC}+\mathrm{PDF}+\mathrm{V} 0 / / \mathrm{EN} \&$ language $=\mathrm{EN} \quad$ (accessed February 15,2013).

Tindemans, Leo. Report on the European Union, Bulletin of the European Communities Supplement 1/1976. http://aei.pitt.edu/942/1/political_tindemans_report.pdf (accessed February 21, 2013).

Tugendhat, Christopher. Europe - What Matters Now, The Swinton Lecture, Cambridge, July 14, 1984. http://aei.pitt.edu/12017/1/12017.pdf (accessed February 21, 2013).

Wallace, Helen; Wallace, William. Flying together in a larger and more diverse European Union. The Hague: The Scientific Council for Government policy, 1995.

Wallace, Helen. "An Institutional Anatomy and Five Policy Modes", Policy-Making in the European Union. eds. Helen Wallace, Mark A. Pollack, Alasdair Young, 6-th ed., 69-107. Oxford: Oxford University Press, 2010.

Warleigh, Alex. Flexible integration. Which Model for the European Union?. New York: Sheffield Academic Press, 2002.

Warleigh, Alex. „Towards Network Democracy? The Potential of Flexible Integration”. In: European Integration in the Twenty-First Century: Unity in Diversity? eds. Mary Farrell, Stefano Fella and Michael Newman, 101-119. London: Sage, 2002.

Warleigh, Alex. Democracy in the European Union: Theory, Practice and Reform. London: Sage, 2003.

Wishart, Ian. "The divisive tax". European Voice, February 21, 2013. http://www.europeanvoice.com/article/imported/the-divisive-tax/76473.aspx (accessed February 21, 2013).

***, ,Charlemagne: Europe à l'Hollandaise. François Hollande's flawed vision for Europe”, The Economist, (February 9-15, 2013), 27.

***. "Community acquis". http://europa.eu/legislation_summaries/glossary/community_acquis_en.htm (accessed February 21, 2013).

***. "Variable geometry". http://europa.eu/legislation_summaries/glossary/variable_geometry_europe_en.htm (accessed February 21, 2013). 